CHARLES JAMES MARTIN, Kt

C.M.G., F.R.C.P., D.Sc., F.R.S.

A. Э. Murch del.) 


\section{Obituary}

\section{CHARLES JAMES MARTIN, Kt, C.M.G., F.R.C.P., D.Sc., F.R.S. (9 January I866-15 February 1955)}

When Charles Martin was born on 9 January 1866 , he received the endowment of the great intellect and the great memory that are indispensable for one who is to be a great scientist. He was born in London and his father, Josiah Martin, was an actuary in a London insurance office. He was considered to be not strong and was sent as a boarder to a private school in Hastings. It seems probable that the magnitude of his gifts was not appreciated, which could happen more easily in those days than now, and he received no specialist training that would provide the necessary scope for their use. From school he went to work in the insurance office where his father was employed, and he was given special tuition in mathematics, but he had no special gift for mathematics, and his talents were probably still undiscovered. Such a postponement of a suitable training did not then have the obvious disadvantages that it has now, and in character building the late recognition of gifts has even to-day the advantage that the temptation to vanity is withheld at the early age when the temptation is most difficult to withstand. Certainly there were no signs that the temptation to vanity had ever existed for Charles Martin.

It was probably at the time when he was working in the insurance office that his tastes began to find their true outlet. He used to relate that he purchased in the Charing Cross Road a second-hand book describing one hundred experiments in chemistry. He performed the one hundred experiments at home and prevailed upon his father to let him read for a scientific degree and study medicine. No subsequent setback occurred; he went to King's College, London, took his B.Sc. degree and was University Scholar and gold medallist in physiology. He studied medicine at St Thomas's Hospital and qualified in 1889 . He then spent some time at Leipzig, studying physiology under Karl Ludwig. With his appointment in 1887 as demonstrator in biology and physiology at King's College, his lifework had already started along the path for which his whole personality was suited. In I $89 \mathrm{I}$ he was appointed demonstrator in physiology in the University of Sydney. He was accompanied to Australia by his wife, Edythe Cross, whom he married just before his departure. His daughter, now Mrs Anthony Gibbs, was born there.

His connexion with Australia which then began continued in one way or another for the rest of his life. The obituary notice in the Medical Fournal of Australia for 28 May I955 shows how fundamentally important to them Australian scientists felt his influence to have been and still to be. Martin remained for 12 years in Australia. He moved to Melbourne where he became lecturer in physiology and, in I90I, professor. He loved teaching and was an inspired teacher, but teaching did not occupy all his time in Australia. With Australian snakes he carried out his brilliant work on snake venoms and the production of antivenoms, which earned him in Igor his Fellowship of the 
Royal Society. He investigated also the anatomy and physiology of monotremes and marsupials, particularly their mode of thermal adjustment, and the development of homoeothermism. The resistance to change in bodily temperature in response to change in environmental temperature was rudimentary in echidna but, in the duck-billed platypus, had reached a somewhat higher level of efficiency, and in marsupials showed a further advance to the state reached by mammals (Martin, r902).

In 1903 the first Australian period ended, and Martin returned to England to become Director of the Lister Institute of Preventive Medicine. For readers of the British Fournal of Nutrition his relationship to the science of nutrition will have the most lively interest. Nutrition interested him more and more. His knowledge of science was very broadly based, which was made possible for him by his tremendous memory. He had at first specialized in physiology, but he had also wide knowledge of bacteriology, biochemistry and pathology; there were few problems in those fields that he could not offer effective help to solve.

The period between Martin's appointment as Director of the Lister Institute and the beginning of the First World War in I9I4 was one of great activity. For 3 years he was Chairman of the War Office Committee on Anti-Typhoid Inoculation, the beneficent fruits of which are well known. Of great dramatic interest was the problem of bubonic plague. It had spread from China to India and was there completely out of control. The India Office applied to the Lister Institute for help, and the proposal was made that a small committee should be set up to investigate how the infection spread. Martin with four others formed the Advisory Committee for Investigation of Plague in India. They organized and controlled the research with a team of two senior members of the Indian Medical Service and two of the staff of the Lister Institute. Martin's name appears no more prominently than the names of others, but his was the guiding and inspiring spirit, on the spot and in England. The fixation of guilt on the rat (Mus rattus and M. decumanus) as the carrier of the disease, and on the tropical rat flea (Xenopsylla cheopis) as the bearer of bubonic plague to man, was a masterly piece of scientific detection.

I first met Professor Martin in I 9 I I when, with Harriette Chick and her young sister, I attended a meeting of the British Association at Portsmouth. I was deeply impressed when Harriette Chick gave a paper on the work she had been doing with Martin on the mechanism and rate of the coagulation of proteins by heat (Chick \& Martin, 1912). She held the position of Assistant to the Director, and continued to do so officially until he retired in January $193 \mathrm{I}$, and unofficially as long as he lived. The paper especially impressed me because I had been familiarized through the botanical teaching of F. F. Blackman with the satisfying concept of optima and limiting factors, and now was introduced to other quantitative biological concepts equally acceptable.

About the same time, I909-10, the nutritional theme began to strengthen with the return from Malaya of Leonard Braddon, an old friend of Martin's. Braddon knew of Eijkman's work in Java, and had become convinced by it and by his own observations of beriberi in human beings that it was a nutritional disease. Braddon convinced Martin, and dietary work with pigeons began at the Lister Institute. E. Ashley Cooper studied the biological side, while Casimir Funk worked at the chemistry of what he 
christened 'vitamine'. The mind of Martin is clearly at work again in this research. Ashley Cooper sought to ascertain the distribution in foods of the substance preventing beriberi. All his experiments aimed at finding the minimum protective or curative dose. Those now familiar with the application of statistical methods to biological tests will find it almost impossible to realize how important this first quantitative stage was, and how long the struggle went on to establish it in the teeth of a complacent qualitative approach.

While the work on the antiberiberi substance was still going on the First World War broke out, and the male staff of the Lister Institute scattered in all directions where it could best be of use. Martin with the rank of Lt.-Colonel served as pathologist with the Australian Army Medical Corps, at first in the Middle East and later in France. In the Gallipoli campaign he organized the laboratory pathological services which were concerned chiefly with enteric diseases, and later carried on the same work in Egypt and Palestine, but here the nutritional theme recurs. Among the soldiers in hospital he observed a disease which appeared to be of nutritional origin and resembled beriberi. He wrote home to the Lister Institute and asked that work should begin, to seek for protective foods suitable for provisioning troops. Ashley Cooper was gone away in uniform, but Harriette Chick was there and Robins, the faithful laboratory man, old style, who understood the care of the experimental pigeons. In this way began the nutritional work that was carried on for so many years under Harriette Chick in the Director's department, which was called the Department of Experimental Pathology, Martin's chair in the University of London being the Chair of Experimental Pathology.

When Martin left the Middle East in I9I7 he went, still with the Australian Imperial Force, to France. He collaborated in adapting the pathological service to conditions in France. Later he was attached to the British Forces, and was in charge

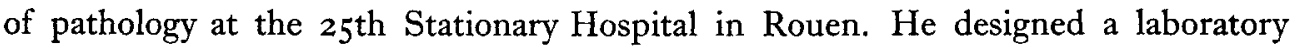
where research could be carried on at the same time as the routine work for this large fever hospital. To his time with the army belong many of the tales that throw light on his personality. He was highly unconventional but not on principle. He did not care about his appearance, and wanted only to be able to work, comfortable and unencumbered. He found the Australian Tommy's tunic with its broad inverted pleat down the back particularly to his liking, and one such tunic was still in use long after the end of the war. I remember somewhere about 1920 bringing a visitor from Central Europe to him in his laboratory at the Lister Institute. The blind was down and the room rather dark. I could feel the horrified gasp when the blind shot up and revealed the Director in his definitely dilapidated khaki. The time in the army gave even more than the usual scope to Martin's wonderful capacity for improvising apparatus. The muscles of his fingers must have been beautifully co-ordinated; the aptitude suited his tastes and he made full use of it. His lovely handwriting witnessed to the same thing; it was regular, elegant and completely unaffected. His was not the scientific personality that needed large and expensive apparatus to give it confidence and importance. He preferred the homely gadget made by himself if it would do the job properly, and he liked others working with him to be able to improvise and tinker too. A well-known dermatologist tells how, in 1917 , he was seconded from the $47^{\text {th }}$ Field Ambulance to 
the 25th Stationary Hospital in Rouen with orders to report to Martin as his senior laboratory technician. The first question fired at him was 'Can you use a soldering iron?' Fortunately for Dr Brain he could solder, and Martin's face lit up when he received the affirmative answer. The door thus unlocked remained open to him ever after. Brain's father had died in 1915, and it seemed financially impossible that he should pursue his medical studies after the war, but Martin took great trouble to ensure that no such waste of talent should occur. Martin loved to gain command over materials. He mastered leather, for instance, and used to repair the shoes of Dr Marjory Little and Sister Eleanor Williams when they were working in Rouen. A cobbler's last was still hanging in his workshop at Roebuck House in the Second World War and when asked about it he said he could use it and would repair our shoes if it came to be necessary.

When Martin got back to his Institute at the end of the First World War, he found that great progress had been made in nutritional research in Britain and the United States. At the Institute some of his workers were longing for the opportunity to test on human beings the application of the work on deficiency diseases which had been done on animals. There was a partial famine in some regions of Europe, especially in Austria, and rickets and a disease called bone softening or adult rickets were reported by the press to be prevalent. Martin was ready, in collaboration with the Medical Research Council, to send a mission from his Institute to investigate the opportunities for research. The mission went in 1919 and brought back the report that conditions were favourable. Rickets, for instance, was so widespread in Vienna that as many cases as were wanted could be found for treatment and, since treatment could not be provided for all that needed it, there would be plenty of untreated cases to act as negative controls. The study lasted 2 years and, amongst many other results, demonstrated unequivocally in the field that cod-liver oil or ultraviolet light could cure and prevent rickets. Martin was in constant correspondence with the mission and, in company with Walter Fletcher, the first Secretary of the Medical Research Council, went to Vienna to counsel and comfort their workers, for naturally there were difficulties on the spot, and an unpleasant controversy about the aetiology of rickets was going on in England.

Martin himself, from the end of the First World War to his retirement in I931, was concerned chiefly with nutritional studies of vitamins and of the biological value of proteins. He and Robert Robison made some drastic balance experiments on themselves to determine the biological value of the proteins in whole wheat, and milk (Martin \& Robison, 1922). Neither of the experimental subjects had a very strong stomach, and the necessary periods on a protein-free diet were very detrimental to both of them. It was directly under Martin's guidance that Margaret Boas Fixsen worked with rats on the biological value of proteins and investigated the nature of egg-white injury, later identified with biotin deficiency.

In 1923 he was awarded a Royal Society medal and in 1927 was knighted. In $193^{\circ}$ he was asked by the Royal College of Physicians to deliver the Croonian Lectures. He chose as subject the thermal adjustment of man and animals to external conditions which he had first studied in Australia and deeply pondered since (Martin, I930a, $b, c$ ). 
Later he came back to the same subject again when, with A. J. Canny, he published an account of the influence of air movement and air conditions on the heat loss from a cylindrical moist body (Canny \& Martin, 1939). The small cylinder used was called 'homunculus', and with it most of the thermic adjustments made by an animal could be imitated.

In I93 I Martin retired from the Directorship of the Lister Institute, but as soon as he was free Australia asked for him again. They wanted him to take charge of investigations on the influence of pastures on wool quality, and from 193 I to 1933 he occupied the chair of Biochemistry and General Physiology in the University of Adelaide, and was chief of the Division of Animal Nutrition of the Australian Council of Scientific and Industrial Research. After he left Australia again he still maintained his Australian interests and connexions.

On his return to England he went to live in Cambridge at Roebuck House, Old Chesterton. It had a garden and various outbuildings where he could have the sort of workshop that he liked, with access to laboratory resources in the university when he wanted them. He was able to carry out a fundamental research on myxomatosis for which Australia felt herself again deeply in his debt. His interest in nutrition was maintained with experiments on the nutritive value of maize for pigs, which were made in Cambridge and, in which, in collaboration with colleagues still at the Lister Institute, light on the problem of pellagra was sought. Workers at the Dunn Nutritional Laboratory had the opportunity to know him and learn the value of his advice, as he became chairman of the Laboratory's Committee.

On the outbreak of the Second World War in 1939, an edict went out in London that all experimental animals must be removed into the country or killed. Work with animals was going on at full strength at the Lister Institute in the Division of Nutrition under Harriette Chick, and evacuation was the only alternative that could be contemplated. Laboratory accommodation was frantically sought, but in vain because much space was needed for a number of researches, all involving animals, and for the very valuable stock colony of rats. Martin found a solution for this as for so many other intractable problems, by offering to receive the refugee laboratory into his own house. Roebuck House with its conservatory and outhouses lent itself to the project. After all, it was once the Roebuck Inn. Martin's skill in improvisation fitted up the conservatory as an animal laboratory, and the old coach house as a biochemical laboratory, nicknamed the Medieval Lab., where gross biochemical work could be done. For finer work accommodation was obtained in the University laboratories. At Roebuck House much nutritional research was done, much discussion was held and much invaluable advice was given. Sir Charles was always at hand with new plans for improving services and keeping out the cold, even to the point of nearly losing his life from pneumonia after fixing up the frozen pipe of the antique boiler that warmed the conservatory, when it burst on a bank holiday.

Martin realized the war to a most bitter extent, and it was a great source of comfort to those of us so fortunate as to work at Roebuck House, that our activities and urgent needs must have greatly mitigated his sufferings, however tiresome we sometimes felt that we must be. Lady Martin, too, never failed in her hospitality to us. Our animal 
laboratory opened directly out of her drawing room, and we were conscious that our smells were sometimes very objectionable, but her graciousness and patience never wavered.

Among the researches carried out at Roebuck House, especially important were those on the nutritive value of the proteins in different foods, which Harriette Chick continued in the direct line of descent from those made in Martin's time at the Lister Institute. The study included the proteins of wheat-flour fractions, of the potato and of an infant food made entirely from plant materials. Through this substitute infant food, the same line of research held straight on to R. F. A. Dean's observations with babies in Wuppertal, and to his researches in connexion with kwashiorkor in East Africa.

All through the war Martin maintained his connexion with Australia through his interest in wool, and in spite of the blitz would set off with his little rucksack on his back to attend the meetings in Leeds of the International Wool Secretariat to which he was scientific adviser.

When in 1946 the Division of Nutrition could at last return to Chelsea, Martin's health had become very precarious. His physical capacity dwindled but his interest in a scientific problem was as great as ever. In one way, one might say, his life was one long crossword puzzle, for his work in solving problems was to him the keenest enjoyment and his curiosity never died. The problem provided his interest, and his pleasure was to find the solution. He did not seem to care at all about the credit for the discovery. His published work does not, therefore, at all adequately represent what he did, for so much of what he thought and suggested was incorporated into the work of those he inspired and helped. The part he ever played was that of the unseen, steering hand. His wisdom was always available in the practical questions affecting life and career as well as in scientific matters, and he did not spare the few salutary words of deflation when they had been well earned.

We have chosen as our portrait of him a drawing made by an Australian artist during the second period in Australia. It is quite different from any other portrait of him, but the artist has caught the glow in his eye from the scientific fire burning within, and anyone who had never seen that look had never seen Charles Martin. Very near the end of his life he was looking at the picture and said to me, knowing that I liked it, 'I think that drawing was prophetic. I look more and more like it every day', so that we have his own authority for using it.

The Australians set up their own memorial to him before he died by founding two Sir Charles Martin Research Fellowships for research in Medical Science to be awarded to young Australians so that they might obtain experience overseas.

The beautifully selected words of the memorial service seem appropriate as a close: 'Let us give thanks to God for the life and work of Charles Martin. For the honesty, simplicity and unselfishness of his character. For his gifts of vision and wisdom and for the powers of his mind, faithfully used for the welfare of mankind in the increase of knowledge, prevention of disease and preservation of health.'

E. M. HUME 
REFERENCES

Canny, A. J. \& Martin, C. J. (1939). F. Hyg., Camb., 39, 60.

Chick, H. \& Martin, C. J. (I9I2). Rep. Brit. Ass. I9I1, p. 281.

Martin, C. J. (1902). Phil. Trans. B, 195, I.

Martin, C. J. (I930a). Lancet, 219, 56I.

Martin, C. J. (1930b). Lancet, 219, 617.

Martin, C. J. (I930c). Lancet, 219, 673.

Martin, C. J. \& Robison, R. (1922). Biochem. f. 16, 407.

\title{
The protective action of vitamin A upon various tissues in the avitaminotic rat, and the sensitivity of these tissues to vitamin A deficiency
}

\author{
BY J. T. IRVING \\ Foint Dental Research Unit of the Council for Scientific and Industrial Research \\ and the University of the Witwatersrand, Fohannesburg \\ AND MARION B. RICHARDS \\ Rowett Research Institute, Bucksburn, Aberdeenshire \\ (Received I Fune I955)
}

The experiments reported here were undertaken to compare the sensitivity of some rat tissues to relative or absolute vitamin A deficiency and to prophylactic doses of the vitamin. That there must be considerable differences in the requirements of various tissues and processes in the rat for vitamin $A$ is suggested by the computed requirements of the entire animal found in the literature, based on such phenomena as growth, tooth colour, vaginal smears, storage, and longevity, recently summarized by Rubin \& De Ritter (1954). The figures given range from 1o to 1000 i.u./kg bodyweight/day.

In the present experiments the changes compared were those that occur in the incisor teeth (Wolbach \& Howe, 1933), the medulla oblongata (Irving \& Richards, 1938-9), the maxillary fundic alveolar bone (Irving, 1949) and the nasolacrimal duct (Irving, Pindborg, Fitzhugh, Weinmann \& Schour, 1952). These were chosen as examples of two hard tissues, epithelia and nerve tissue. A preliminary account of some of these findings has already been published (Irving \& Richards, 1954).

\section{EXPERIMENTAL}

\section{Management of rats}

Young albino or hooded Lister rats were used. Their mothers were given stock biscuits till the young were $\mathrm{I} 6$ days old. Then, as in previous experiments (Irving 8 Richards, I938-9), the mother was placed on the same vitamin A-free diet as previously 